\title{
12. Urban Aboriginal ceremony: when seeing is not believing
}

\author{
KRISTINA EVERETT
}

I am an anthropologist. Like all anthropologists my research methodology is entrenched in participant observation fieldwork and like many anthropologists, my writing practice is primarily ethnographic. Following Ortner, ethnography encompasses many things, but minimally means 'the attempt to understand another life world using the self - as much of it as possible - as the instrument of knowing'. ${ }^{1}$ That is, through long-term embodied engagement in relationships with research participants and their life worlds the researcher learns. By analysing one's own experience of learning about an 'other' life world the classical ethnographer is committed to writing what Geertz called a 'thick description'. ${ }^{2}$ Ortner argues that such classical ethnographies produce understanding through richness, texture and detail. The 'thick, descriptive' ethnography that I write is inseparable from the participant observation fieldwork that I conduct. The writing occurs synchronously with the fieldwork. Texts including field notes, journal entries, letters, emails, photos and videos, which are not raw data, but necessarily a form of analysis and interpretation, and are later refined into articles like this one. Of course, the practice of immersion in others' worlds is problematic, partial and constrained, but, as Ortner makes explicit, an ethnographic approach is as much 'an intellectual positionality, a constructive and interpretive mode, as it is a bodily process in space and time'. ${ }^{3}$

The story that I tell here is my story of learning about the connection that a group of urban Aboriginal people make between a post-contact Aboriginal creation myth and their own version of a funeral ceremony. It is an ethnographic account of a ceremony that is not a 'traditional' Aboriginal ceremony, but one which is claimed by those who perform it as an expression of their still emerging identity. These people claim traditional Aboriginal ownership of a large part of what is now a modern Australian metropolis and are struggling to produce representations of this identity after a long period of dispossession and

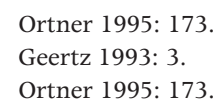


marginalisation. They struggle because their claim is a big one, and there are many competing claims from other Aboriginal groups as well as the Australian state. They also struggle because they have been dispossessed of both their land, and of their traditional cultural practices. All they have to represent their Aboriginality now are practices that they have 'borrowed' from other Aboriginal groups, those that have been passed down through families as partial memories, those they have seen in films and advertisements, and those they develop from the dreams and imaginations of senior people. I use the pseudonym, 'Gwalan' to refer to them here because of fraught politics that I will describe below.

Gwalan have emerged in the last 30 years or so as 'a people'. Prior to their emergence as a named group, some of the people who now call themselves Gwalan lived as groups of disparate people living on the fringes of Australian society and identifying themselves as Aboriginal. They named themselves according to their attachment to specific suburbs, roads or creeks calling themselves 'Bridge Road Mob', or 'Platypus Creek Tribe' for example. Some people who now identify as Gwalan did not, however, know that they possessed Aboriginal heritage until academics including linguists, archaeologists, biologists, historians and anthropologists began researching Gwalan history and compiling genealogies.

Three to four hundred people now identify and are identified as Gwalan and continue to develop various ideas, values and philosophies about and expressions of their identity. Some are engaged in the various expressions of cultural renaissance and revival of Aboriginal traditions that characterise some aspects of Gwalan (re)emergence. These include singing, dancing, painting and various kinds of ceremony. Others, however, expressly do not engage in these kinds of cultural expressions and instead choose to represent themselves using different kinds of political methods including academic research, formal political speeches, protests and petitions. Not only, in fact, do these more formally politically represented Gwalan not engage in singing, dancing, painting and ceremony, but they actively and vocally dispute the authenticity of such representations claiming that they do not represent 'true' Gwalan heritage. The ceremony that I describe later and its effects are the cultural products of a group of about 150 Gwalan who are faced with the hostility and denigration of other Gwalan. Regardless of this, the ceremony has been performed regularly for at least 25 years and those who perform it now claim it as Gwalan tradition.

The very identity 'Gwalan' has been queried by outsiders, both Aboriginal and non-Aboriginal. In part, this is because this recent Indigenous identification has occurred in the era of land rights and native title. According to the Native Title Act 1994 (Clth), claimants must prove that they are still 'attached' to a 'body of traditions, observances, customs and beliefs of Aboriginal people or a community or group of Aboriginal people, including those traditions, observances, customs and beliefs as applied to particular persons, sites, areas 
of land, things or relationships'. Because Native Title claims are arguably the ultimate recognition of Indigenous 'authenticity' by the Australian state, many Indigenous Australians struggle to conform to its demands. These demands, as Povinelli argues, are difficult enough for any Indigenous group to prove, but are virtually impossible for people who live in long colonised areas as Gwalan do. ${ }^{4}$ There have been a number of (unsuccessful) Gwalan native title claims, generating considerable historical research.

Because Gwalan 'ethnogenesis' coincided with land rights, native title, and other state policies concerning recognition of Indigenous Australians' rights, it might be argued that it was an identity created to take advantage of those policies. This may indeed have been the reason at the time, or at least part of the reason. However, my experience of participating in and observing the practices that Gwalan today call their culture - ceremonies, dance, painting and language revival - leads me to take the view that whatever the earlier reasons for their development, these things have become such values in themselves that Gwalan cannot and will not relinquish them. These practices sustain group and individual dignity and self respect. One young Gwalan man told me that 'Without my culture I'm nothin'. ${ }^{5}$

Before I go any further, it is important that I explain what I mean by 'tradition' as it is practiced in the Gwalan context. Manning Nash insists that although tradition is mostly concerned with the past and is hence fundamentally backward-focused, it does have a future dimension. ${ }^{6}$ This dimension involves the commitment of its carriers to preserve and continue traditional practices into the future. However, because of radical, long term disruption of cultural practices and because they have inter-married with many different groups of Aboriginal and non-Aboriginal peoples, Gwalan do not have one, common cultural tradition on which to draw. They consequently 'shelve' or 'sideline' all traditions other than their new Gwalan tradition. Everyone in the community is encouraged to be part of the project of producing this 'new tradition' and many are committed to preserving and continuing what are now claimed as traditional Gwalan cultural practices. As well as public spectacles including dancing, 'welcome to country' speeches and art exhibitions, Gwalan conduct private ceremonies meant for the benefit of their own members.

Not only have traditions changed to the point of being unrecognisable from the early records of colonists, but they also have become 'mixed up' with the traditions of other Indigenous and non-Indigenous peoples. Many currently practiced Gwalan traditions bear strong resemblance to practices described

4 Povinelli 2002: 39.

5 Everett, Fieldnotes, Euroka Clearing, September 2003.

6 Nash 1989: 14. 
in the traditional Aboriginal anthropological literature and belong to people other than Gwalan. One example of these practices is the painting of ' $\operatorname{dot}^{\prime}$ paintings that are more usually associated with paintings from the Central Desert. Another is traditional Aboriginal dancing dressed in loin cloths with symbols painted in white ochre marked on the dancer's skin. Some are based on the memories, imaginings and dreams of older Gwalan descendants. Other Gwalan traditions might have their origins in indigenous cultures from other countries, reflecting a kind of 'global indigeneity'. Cultural exchange, support and collaboration between Indigenous groups around the world have grown in recent times, enabled and supported by new technologies including the internet, more accessible travel, and increased participation in global markets (especially art markets). ${ }^{7}$ The trouble is that because these traditions do not originate, or cannot be proved to have originated, with Gwalan ancestors who lived in Gwalan country before 1788 they do not conform to the demands of native title and consequently do not conform to dominant ideas concerning Aboriginal 'authenticity'.

All Gwalan descendants are dislocated in significant ways from their heritage. Gwalan language is no longer spoken, although a version has been revived from the records of early British colonists and is used ceremonially in 'Welcome to Country' ceremonies. ${ }^{8}$ Detailed knowledge of traditional kinship relations is no longer transmitted, and many Gwalan stories relating to specific places in Gwalan country cannot be remembered. They are not, however, displaced from their traditional country and although they have been forcibly separated from religious systems that gave particular meanings to their connection to land, they claim today that some knowledge, rituals and stories have survived and are now being implemented in their contemporary quest to experiment with new ideas about spirituality and land. These ideas, as I will describe, are adaptations of past and present beliefs, histories, relationships and politics.

According to Gwalan, their Dreaming revolves around stories, beliefs and rituals concerning a Gwalan ancestor figure, Baiame. The name Baiame is not arbitrary. The belief in an 'All-Father' inhabiting the heavens by Aboriginal peoples in south-eastern Australia was first documented in 1875 as occurring at Wellington Valley Mission. ${ }^{9}$ Here, Ridley quotes the Reverend James Gunther as saying:

There is no doubt in my mind that the name Baia-mai ...

Refers to the Supreme Being; and the ideas concerning

Him by some of the more thoughtful Aborigines are a

\footnotetext{
Cf Sissons 2005: 7-34.

See Everett 2009: 53.

Ridley 1875: 135 in Swain 1993: 154.
} 
Remnant of original traditions prevalent among the ancients of the Deity. ${ }^{10}$

Baiame and his cult as it was practised late in the nineteenth and around the turn of the twentieth century is referred to in Manning, Cameron, Howitt, Mathews, and Lang with later authors including Elkin, Lane, Kolig, Maddock, and Swain also making reference to the cult. ${ }^{11}$ Apart from using the name Baiame there is only one current practice performed by Gwalan that has any resemblance to those described in the literature. This practice is the carving of dendroglyphs: images or designs in the trunks of living trees. Although the group carve images in trees, the form of the carvings and the rituals associated with them bear no resemblance to the cult of Baiame as it is documented in the literature.

Dendroglyphs seem to have been carved exclusively in the south-east of the continent and are described by Lane as highly abstract geometric designs although some depicted European things such as trains, ships, horses, cattle, pigs and effigies of Europeans themselves. ${ }^{12}$ Lane suggests that these carved trees may have served to represent Baiame's camp and gifts. Regardless of conjecture about the form and significance of dendroglyphs in the past, those made by Gwalan are an emblem for the group. All these dendroglyphs are images of turtles. Turtles are a modern Gwalan symbol of survival, longevity and, as land and water dwelling animals, adaptability.

The carving of the turtle image into the tree is part of a ceremony that is believed, community members tell me, to facilitate the transport of the spirit of a recently deceased community member from this earthly realm into the spiritual realm in the sky that is presided over by Baiame. Everyone I asked claimed that Baiame and his cult belong to Gwalan and that Baiame ceremony is their Dreaming.

Yet, when asked, many community members say that they are Roman Catholic. There is a strong connection between the community and a Catholic Centre in an outer suburb of the city. This link is an extension of long term associations many people have through family histories involving Catholic missionisation. Of those who do not have a history of missionisation, many do have a history of intermarriage with English and Irish Catholic convicts and free settlers. However, I do not think that this history is all that makes many Gwalan claim to be Catholic now. The Catholic Centre has become very much a community focus because some important community ceremonies such as weddings, funerals and Christenings are performed there. Many Gwalan are recipients of Catholic welfare through the Centre. The Centre also provides transport, a venue and

10 Ridley in Swain 1993: 127.

11 Manning 1882: 170; Cameron 1885: 364-365; Howitt 1904: 440-504; Mathews 1905; Lang 1899: 53; Berndt 1947: 334; Elkin 1975: 143; Lane 1978: 233; Kolig 1989: 255-256; Maddock 1982: 127; Swain 1997.

12 Lane 1978: 233. 
programs which allow community members to engage in social interaction with each other and other local Indigenous peoples. In other words, the Centre and Catholicism provide Gwalan with much valued resources. Arguably, the most valuable of these resources are potential new members of the community. The Centre is an important source of new membership because it facilitates contact between Gwalan and other Indigenous people who now live on what is claimed as Gwalan land. These Indigenous people from other places may be searching for culturally appropriate ways to make more meaningful connections with that land.

It may seem that being Catholic and having Dreaming might be an impossible contradiction. Clearly Gwalan do not recognise a contradiction. The group routinely includes reference to Baiame in their Catholic rites. One example was a Christening I attended at the Centre, which, although presided over by a Catholic priest, included ceremonies and prayers associated with Baiame. It seems that the political and social value of having Dreaming is equal to the political and social value of being Catholic. Both are indispensible to the survival of the community. Having Dreaming authenticates Aboriginality and Gwalan claims. It also provides important symbolism relating to Gwalan identity. Being Catholic provides valuable material resources, and arguably even more importantly, precious new members without whom the community would have a hard time reproducing itself over time due to its small numbers.

\section{The Burial Tree Ceremony}

It had been six weeks since Uncle Sam passed away and the community had done their crying. Because Uncle Sam had been a Vietnam veteran and a high ranking police officer, a state funeral had been performed in the days after his death. The funeral had been attended by some community members, but their attempts to have input into 'Indigenising' the event had been thwarted by officialdom. The only signifiers of the deceased's Aboriginal identity were the little ribbons of red, yellow and black that his sisters wore pinned to their jackets. There had been considerable disgruntlement in the community since that day; many people told me that they thought it was disrespectful that the deceased was not honoured with an 'Aboriginal funeral'. When I asked what constituted an Aboriginal funeral people were quite confused, but the sentiment was perhaps most eloquently expressed by an old man when he said, 'Well, we get to do it our own way'. ${ }^{13}$

Uncle Sam's funeral was taken over by state symbolism because of his status in the broader Australian society. In most cases however, Gwalan can arrange their

13 Everett, Fieldnotes, April 2005. 
own 'Aboriginal funeral' for deceased community members, within the limits of the law concerning the disposal of the body. Burial Tree Ceremonies, because they do not involve disposal of the body, are autonomous affairs performed in addition to other ceremonies. In Uncle Sam's case, the performance of a Burial Tree Ceremony six weeks after the state funeral gave Gwalan the opportunity to redress what some considered to be state intervention in community business. It also had the effect of affirming group identity by articulating the Aboriginal identity of the deceased and of the community.

It was explained to me that Uncle's spirit had used the time between death and ceremony to revisit all of its favourite people and places in the earthly realm. The ceremony would put an end to the spirit's wandering this world and facilitate its movement into another realm. On a cold winter's morning, I was invited to a site in a National Park west of the city to participate in the Burial Tree Ceremony. This ceremony, it was said, would send Uncle's spirit to the 'sky people'. Sky people, Gwalan tell me, are the spirits of ancestors who, before white people came to Australia, would have inhabited sacred places in Gwalan land. Now that these sites have been colonised by white Australia the spirits of Gwalan ancestors have been forced to relocate to the sky.

It is not possible to drive vehicles close to the site where a number of Burial Trees are situated. These trees have been scarred with designs during earlier Burial Tree Ceremonies. During the ceremony I describe below, a new tree is added to those at the site. When I arrived at the site and crossed a small dry creek bed from the site I had a clear view, however, of the six trees that, at that time, had already been scarred (sadly there are five more scarred trees there now). I also saw an open space (clearing) for camping, and an already burning fire in the middle of the clearing. There were 30 or so Gwalan adults and about 15 children. Adults were engaged in making and drinking tea, preparing food, chatting with each other and generally milling around. Many of the children were busy chasing the numerous Eastern Grey kangaroos which have been introduced to the park, and which constantly haunt the clearing in the hope of finding food.

As I approached the site, I was warmly greeted with the usual jokes and teases that I habitually trade with appropriate people and the more respectful greetings that are reserved for senior people. The general ambience was far from the sombre mood that might be expected of a funeral rite. There was a general air of anticipation if not excitement - something was going to happen.

Gwalan themselves refer to all of their more formal gatherings as ceremony including social gatherings and they also claim that the Burial Tree Ceremony involves ritual acts. These acts include the carving and grouting of the tree trunk. The performance of these acts is considered essential so that the spirits 
of the recently dead can pass from the earthly realm into the spiritual realm of the 'sky people'. Ritual must surely be understood in essence to be a specifically communicative action - an action that affirms culturally binding meaning and emotion. These acts, as I recount below, are also said, by Gwalan, to achieve other transformations, transitions and confirmations such as the transformation of the tree into an emblem of Gwalan identity as dendroglyph.

The first 'ritual act' constituting the Burial Tree Ceremony for Uncle Sam was the choosing of a tree which would serve as an appropriate focus for the ceremony by a group of elders, both men and women. Burial Trees are always estimated to be older than 200 years and are species known for their longevity. The tree for this particular ceremony was chosen within a grove of trees which exhibit the re-worked scars of earlier Burial Tree Ceremonies. The first Gwalan engraving ceremony occurred 30 years ago. This ritual, some people told me, should be repeated twice a year, but has occurred less frequently in my experience. This may be because there has been at least one death every year in recent years and 'renewal' rituals have been incorporated into 'full blown' ceremonies for new trees. Nevertheless the designs are re-grooved and re-grouted with white ochre paste often enough that the designs in the trees always look reasonably 'fresh'.

Gwalan men were busy removing a large, oval shaped piece of bark from the chosen tree so that the turtle design, which would be carved into the 'flesh' of the tree, would have a 'new', 'clean' space. When I asked a senior man whether the bark's removal would damage the tree, he replied:

We never hurt trees ... Jest look at them other fellas [trees]

What we done before. They's all lookin' good. I told ya before

We choose these trees 'cause they older' $n$ two hundred years.

More'n whitefellas been 'ere. They been missin' us them oldfella [trees]. They been cryin' for us. Ceremonies.

I tell ya what really hurts these oldfella trees. They been taken away from us - from their own real people. Now we're back an' these oldfellas [trees] need to get that whitefulla stuff off them [bark grown since colonisation].

We gotta clear a space for the old ways again. Got to take off the whitefella bark. It don't hurt 'em. ${ }^{14}$ 
It seems that by removing the bark that 'belongs' to whitefellas, Gwalan 'open up' the tree to make a space for their own stories to be told. They make a symbolic 'clearing' on the tree, in time, in space in which to put their own story.

The National Park where Gwalan perform the Burial Tree Ceremony is regularly visited by groups of international tourists and their local guides who can be confident of sighting wildlife including many bird species, goannas and kangaroos. The Burial Tree Ceremony was in progress when a group of about 20 tourists accompanied by a tour guide unexpectedly encroached on the proceedings. These unwanted and unexpected on-lookers crowded about the tree as the men were carving. Yet, no matter how unwelcome such intrusion on Gwalan practices may be, the tourists were 'entitled' to be there. As part of a National Park, the ceremonial site is 'public place', not Gwalan place. The tour guide, employee of a private tour company and unknown to Gwalan, proceeded to present an authoritative commentary to the tourists explaining (wrongly) that the carved trees delineated a prehistoric space for dance and claimed that Aboriginal ceremony is no longer performed there. In other words, the tour guide denied the existence of Gwalan ceremony at the very moment of its expression.

The dismissive utterances of the tour guide, however, provided the opportunity for a senior Gwalan descendant woman and sister of the deceased to exhibit the ways in which Gwalan performance and Gwalan identity exists as that which is negotiated between Gwalan and non-Gwalan as well as between Gwalan. The Gwalan woman literally took the high ground by standing above the tourists on the high side of a slope. Below is a transcript, taken from a video, of what she said:

Excuse me. This is not a dance ground. This is a ceremonial ground and you mob are standing in it and watching a Burial Tree Ceremony. This is the place where our people are taken by Baiame to be with the sky people. This is my brother. Over there is my mother. That one up there is me. We are [Gwalan] and we have always had ceremony here. It's jest that yous don't know about it. ${ }^{15}$

The Gwalan woman's words are a political claim to country and to relationships with country and other Gwalan past and present. It was an explanation of the proceedings that included an explanation of beliefs associated with the cult of Baiame, which Gwalan call their Dreaming. The use of Baiame stories in this context provided political linkages to a tradition that claims authentic Aboriginal identity in relations with non-Gwalan. They are, of course, more than that; the link to the cult of Baiame is inextricable from Gwalan ritual practice and from

15 Everett, Video, Euroka Clearing, July 2003. 
their emergent and emerging group identity. Links between Dreaming, land and authentic identity are made explicit. As the woman's final words reiterate: 'we have always told our stories and performed our ceremonies. 'Yous fellas jes' don't know about them'. The Gwalan woman's claims were a demonstration of how emergent Gwalan identity must, necessarily take shape against and within the very terms of denial that 'outsiders' assert. Gwalan take opportunities to mitigate negative judgments by affirming their identity in response to those negative terms. This was done in this case by asserting the difference between Aboriginal knowledge as Dreaming and western knowledge as denial.

When I asked a number of Gwalan what they thought about the tourists and their intrusion their responses were mainly ambivalent. Most people saw the political necessity of explaining their presence and practices to whites, but noone I asked was happy about what was considered a rude intrusion. One old lady's poignant response was:

Whitefellas never see what's in front o' their nose. They's jes' gotta be told. Nothin' else for it. Jes' gotta be told. But it's exhaustin'. Git tired o' tellin' 'em. Why can't they jest leave us be? ${ }^{16}$

\section{Authenticity, tradition, and Dreaming stories}

It can be seen from my ethnographic description of the Burial Tree Ceremony that Gwalan have a significant 'authenticity' problem. The main reason for general reluctance to accept the authenticity of Gwalan cultural practices is because it has been widely documented, represented and subsequently believed, in various discourses, that urban Aboriginal traditions, especially urban religious traditions are, today, defunct. Tench and Collins began the depressing tale of the social and religious obliteration of south-eastern Australian Aboriginal societies. ${ }^{17}$ It is story that has been picked up more recently by historians including Reynolds, Aplin and Goodall; by sociologists and political scientists such as Broome, Rowley and Jacubowicz; by linguists including Eades, Troy, and Walsh and Yallop; and by economists like Altman and Niewenhuysen. ${ }^{18}$ Anthropologists making a similar point have included Stanner, Berndt, Barwick, Reay, Gale, Williams, Rumsey and Sutton, to name a few. ${ }^{19}$

Most accounts of urban Aboriginal practices in every discipline associated with Aboriginal Studies discount the possibility of surviving Aboriginal religious

16 Everett, Fieldnotes, Euroka Clearing, July 2003.

17 Tench 1788; Collins 1788.

18 Reynolds 1998, 1989; Aplin 1988; Goodall 1995; Broome 1996; Rowley 1972; Jacubowicz 1994; Eades 1976; Troy 1990, 1993; Walsh and Yallop 1993; Altman and Niewenhuysen 1979.

19 Stanner 1968; Berndt 1962; Barwick 1962: 88; Reay 1964; Gale 1977: 45; Williams 1988; Rumsey 1994; Sutton 2001: 125. 
practices in cities. Cowlishaw, for example, argues that to attribute any kind of traditional knowledge to suburban Aboriginal elders is a form of racial essentialism - a false assumption that Aboriginality is somehow 'naturally' imbued with knowledge of ancient traditions. ${ }^{20}$ This may indeed be true in some, or even most cases, but is not necessarily always the case and depends very much on what precisely 'counts' when we are talking about tradition and custom.

Owing largely to the crucial importance of being able to demonstrate 'tradition' and 'on-going connections to customs' in land rights and native title claims, some anthropologists and other academics have been testing the waters to see exactly what counts as tradition and on-going connections when they prepare reports for court cases. They have demonstrated that the legislation can be interpreted in different ways. Recent anthropological work in this area argues for recognising specific kinds of continuity in various urban and rural Aboriginal cultural forms that may have been previously discounted because they have changed over time. Among these new approaches are those of Taylor, the more recent work of Beckett, Merlan, and Macdonald, as well as my own work. ${ }^{21}$ These newer ethnographies are set against discourses that have allowed Aboriginal tradition to be placed only in past practices which may only be continuous in areas remote from the polluting effects of western civilisation and which are said not to exist in the modernity of western towns and cities.

Do Gwalan have 'Dreaming'? I use the term 'Dreaming' here in a broad political way reflecting a generalised acknowledgement of Aboriginal spirituality, not in any specific sense. I acknowledge that there are many different 'Dreamings', as indeed, there are many different words in Aboriginal languages pertaining to concepts related to 'Dreaming'. I also acknowledge that the term 'Dreaming' is an extremely imprecise translation of immensely complex systems of meaning. Yet, what is important in this context is that Gwalan themselves say they 'have' Dreaming, and that they perform ceremonies and tell stories which are connected with a spiritual world-view that draws from Aboriginal heritage. 'Having Dreaming' also produces particular effects for Gwalan. Ceremonies associated with Dreaming effect particular transformations, transitions and confirmations, and support culturally binding beliefs.

Perhaps as importantly as effecting ritual transformations and affirming identity within the group, 'having Dreaming' is also a primary marker of 'authentic' Aboriginality according to dominant discourses concerning what constitutes 'real' Aboriginal tradition. It cannot be a real Aboriginal painting if it does not have a Dreaming story. It cannot be a real Aboriginal dance if it is not a

20 Cowlishaw 2009 (in press): 16.

21 Taylor 2005; Beckett 1996; Merlan 2006; Macdonald 2004; Everett 2009. 
Dreaming dance. People are not really Aboriginal unless they 'have' Dreaming stories. So, if 'having Dreaming' contributes to the 'authenticity' of a given group of Aboriginal people, then the interpretation of what counts as Dreaming becomes less an analytical problem than a political one. That is, academic arguments including those of Rumsey, Merlan, Maddock, Turner, and AustinBroos among others, concerning what, precisely 'counts' as myth and what constitutes history are less important in the context of Gwalan than the political advantage that Gwalan gain from calling their 'stories' Dreaming stories. ${ }^{22}$ In other words, if Aboriginal peoples can convince the wider Australian society that they have Dreaming, that is, that they are spiritual, they are thought to be 'authentic'. This is because dominant Australian discourses 'essentialise' Aboriginality and conceptualise it as the binary opposite of westernness. 'We' western thinkers cannot escape our own traditions of thought, which place 'real' Aboriginal people into the category of 'primitive'. Aboriginality is conceptualised as 'spiritual', while westernness is conceptualised as 'material' (or modern). This kind of binary opposition serves to substantiate the identity of Aboriginal peoples for the purposes of native title.

The irony of this is that the Gwalan people I work with know that they cannot win a native title claim under current law because they have tried and failed. But 'we' whites can afford to believe in Gwalan Dreaming precisely because we are not threatened by it. We know that they cannot win a native title claim for the same reason that Gwalan do. The political advantage that Gwalan gain from 'having Dreaming' is that it affirms their claims to identity as difference. Dreaming produces narratives which support claims to distinctive Aboriginal identity because these stories articulate the difference between Gwalan and non-Gwalan. In this way, Gwalan Dreaming affirms Gwalan 'authenticity'.

Of course, claims to authenticity are highly problematic. Even though the category 'authentic' is inherently flawed, power inflected and political because it is always the powerful that impose the category (or withhold it) from the less powerful, it still has the potential to damage legitimate claims and to support dubious ones. ${ }^{23}$ The group of Gwalan I work with are fragile, marginalised and powerless, not only in relation to the wider Australian non-Aboriginal society, but also in relation to the other group of Gwalan to which I refer earlier. The other Gwalan group is larger and has the long-term support of a number of senior academics including linguists, archaeologists, biologists and historians who support their claims. These claims, as I have said, are based on evidence produced by western research, which, in turn, supports the careers of the other Gwalan group's academic supporters. The 'primitive', 'inauthentic' representations made by the Gwalan group I work with are regarded, by the

22 Rumsey 1994; Merlan 1995; Maddock 1988; Turner 1988; Austin-Broos 1994.

23 Cf Everett 2008: 147. 
other group and their supporters, as a threat to the 'authenticity' of all Gwalan. They are consequently denied by the other Gwalan group, and it seems, by just about everyone except those who practise them.

Indeed, the Gwalan stories I recount above defy categorisation. They do not fit into anthropological, historical or mythological analysis. They fail, necessarily, to live up to the criterion demanded to reach the status of myth proper or Dreaming story. Yet they also, necessarily, perform the same kinds of effects. Thus, what is important in my view is that Gwalan call these stories Dreaming stories. Whether this is right or wrong from the point of view of anthropological theory, and whether anthropology can ever understand these stories better by calling them something else, does not affect the cultural and political power of these stories to articulate Gwalan identity.

\section{Conclusion}

Gwalan claim that the Burial Tree Ceremony involves acts which are considered essential for the spirits of the recently dead to pass from the earthly realm into the spiritual realm of their ancestors, the 'sky people'. This enacts other transformations, transitions and confirmations including the transformation of the tree into an emblem of Gwalan identity as dendroglyph. Practices and stories related to the cult of Baiame invoke the ancestral spirits of Gwalan land and relationships between Gwalan and non-Gwalan and facilitate the relationships between Gwalan ancestors and Gwalan. As this chapter demonstrates, this is sometimes done before the eyes of those who not only deny the 'authenticity' of the acts and the reality of their effects, but the very presence of ceremony and people performing it.

Histories of extermination, internment, assimilation and self determination of Australian Aboriginal peoples have been well documented. Accounts of ceremonies and various kinds of cultural practices saturate the literatures of various disciplines. In the context of claims to land, courts hear countless representations of Aboriginal traditions, customs and culture. Advertisements, news stories and documentaries constantly present images of Aboriginal people as pristine primitives, troublesome rebels, or tragic wrecks. Aboriginal academics and authors challenge these representations and make their own. Aboriginal artists have gone some way to represent their culture in their own terms. What is less documented and less recognised is that the representations of the majority of Aboriginal people, urban people, are often not recognised or recorded at all. 
Passionate Histories

\section{References}

\section{Primary sources}

Everett, Fieldnotes, July, September 2003, Euroka Clearing.

Everett, Fieldnotes, April 2005.

Everett, Video, Euroka Clearing, July 2003.

\section{Secondary sources}

Altman, J and J Niewenhuysen 1979, The Economic Status of Australian Aborigines, Cambridge University Press, Cambridge.

Aplin, Graeme 1988, A Difficult Infant: Sydney Before Macquarie, University of New South Wales Press, Sydney.

Austin-Broos, Diane 1994, 'Narratives of the encounter at Ntaria (Aboriginal histories, Aboriginal myths)', Oceania 65(2): 131.

Barwick, Diane 1962, 'The self conscious people of Melbourne', in Aborigines Now, M Reay (ed), Angus and Robertson, Sydney.

Beckett, Jeremy 1996, ‘Against nostalgia: place and memory in Myles Lalor's oral history', Oceania 66(4): 312.

Berndt, Catherine 1962, 'Mateship or success: an assimilation dilemma', Oceania 33(2): 88 .

Berndt, Ronald 1947, 'Wiradjeri magic and clever men', Oceania 17: 334.

Broome, Richard 1996, Historians, Aborigines and Australia, Allen \& Unwin, Sydney.

Cameron, ALP 1885, 'Notes on some tribes of New South Wales', Journal of the Anthropological Society of Great Britain and Ireland 14: 364.

Collins, David 1975[1788], An Account of the Colony in New South Wales Vol. 1, University of Chicago Press, London.

Cowlishaw, Gillian 2009, The City's Outback, University of New South Wales Press, Sydney.

— 2009 (in press), 'Suburban mythology', The Australian Journal of Anthropology.

Eades, Diana 1976, The Dharawahl and Dhurga Languages of New South Wales South Coast, Australian Institute of Aboriginal Studies, Canberra. 
Elkin, AP 1975, The Aboriginal Australians, Longmans, London.

Everett, Kristina 2008, 'Too much information: when the burden of trust paralyses representation', in Indigenous Biography and Autobiography, Peter Read, Frances Peters-Little and Anna Haebich (eds), Aboriginal History Monograph 17, Aboriginal History Inc, Canberra: 147-157.

— 2009, 'Welcome to Country - not', Oceania 79(1): 53-65.

Gale, Fay 1977, 'Aboriginal values in relation to poverty in Adelaide', in Aborigines and change: Australia in the '70s, RM Berndt (ed), Australian Institute of Aboriginal Studies, Canberra: 45-52.

Geertz, Clifford 1993, The Interpretation of Cultures, Fontana Press, London.

Goodall, Heather 1995, 'New South Wales', in Contested Ground: Australian Aborigines Under the British Crown, A McGrath (ed), Allen \& Unwin, Melbourne: 62-74.

Howitt, AW 1904, The Native Tribes of South East Australia, Macmillan, London.

Jacubowicz, Andrew (ed) 1994, Racism, Ethnicity and the Media, Allen \& Unwin, St Leonards, New South Wales.

Kolig, Erich 1989, Dreamtime Politics: Religion, World View and Utopian Thought in Australian Aboriginal Society, Dietrich Reimer Verlag, Berlin.

Lang 1899, 'Australian gods: a reply', Folklore 10(1): 1-46.

Lane, KH 1978, 'Carved trees and initiation ceremonies on the Nambucca River', in Records of Times Past: Ethnohistorical Essays on the Culture and Ecology of the New England Tribes, Isabel McBryde (ed), Australian Institute of Aboriginal Studies, Canberra: 222-234.

Macdonald, Gaynor 2004, 'Photos in Wiradjuri biscuit tins: negotiating relatedness and validating colonial histories', Oceania 73(4): 225.

Maddock, Kenneth 1982, The Australian Aborigines: a Portrait of their Society, Penguin, Ringwood.

- 1988, 'Myth, history and a sense of oneself', in Past and Present: the Construction of Aboriginality, Jeremy Beckett (ed), Australian Institute of Aboriginal Studies, Canberra: 42-57.

Manning, J 1882, 'Notes on the Aborigines of New Holland', Journal and Proceedings of the Royal Society of New South Wales 16 : 170. 
Mathews, RH 1905, Ethnographical Notes on the Aboriginal Tribes of New South Wales and Victoria, Government Printer, Sydney.

Merlan, Francesca 1995, 'The regimentation of customary practice: from Northern Territory land claims to Mabo', The Australian Journal of Anthropology 6(1-2): 167-183.

- 2006, 'Explorations towards intercultural accounts of socio-cultural reproduction and change', Oceania 75(3): 64-83.

Nash, Manning 1989, The Cauldron of Ethnicity in the Modern World, University of Chicago Press, Chicago.

Ortner, Sherry 1995, 'Resistance and the problem of ethnographic refusal', Comparative Studies in Society and History 37: 173-193.

Povinelli, Elizabeth 2002, The Cunning of Recognition: Indigenous Alterities and the Making of Australian Multiculturalism, Duke University Press, Durham and London.

Reay, Marie 1964, Aborigines Now, Angus and Robertson, Sydney.

Reynolds, Henry 1989, Dispossession: Black Australians and White Invaders, Allen \& Unwin, St Leonards, New South Wales.

— 1998, This Whispering in our Hearts, Allen \& Unwin, St Leonards, New South Wales.

Rowley, CD 1972, The Destruction of Aboriginal Society, Penguin, Ringwood.

Rumsey, Alan 1994, 'The dreaming, human agency and inscriptive practice', Oceania 65: 116.

Sissons, Jeffery 2005, First Peoples: Indigenous Cultures and their Futures, Reaktion Books Ltd, London.

Stanner, WEH 1968, White Man Got No Dreaming, Australian National University Press, Canberra.

Sutton, Peter 2001, 'The politics of suffering: Indigenous politics in Australia since the 1970s', Anthropological Forum 11: 125.

Swain, Tony 1993, A Place for Strangers: Towards a History of Australian Aboriginal Being, Cambridge University Press, Melbourne.

Taylor Luke 2005, 'Manifestations of the mimih', in The Power of Knowledge: the Resonance of Tradition, L Taylor, G Ward, G Henderson, R Davis and L Wallis (eds), Aboriginal Studies Press, Canberra: 34-50. 
Tench, Watkin 1996[1788], 1788, T Flannery (ed), The Text Publishing Company, Melbourne.

Troy, Jakelyn 1990, Australian Aboriginal Contact with the English Language in New South Wales: 1788-1845, Pacific Linguistics, Australian National University, Canberra.

Walsh, M 1993, 'Language contact in early colonial New South Wales', in Language and Culture in Aboriginal Australia, M Walsh and C Yallop (eds), Aboriginal Studies Press, Canberra: 64-76.

- 1993, 'Introduction', in Language and Culture in Aboriginal Australia, M Walsh and C Yallop (eds), Aboriginal Studies Press, Canberra: 4-12. 